\title{
Endosperm of Angiosperms and Genomic Imprinting
}

\author{
Elizabeth L. Kordyum * and Sergei L. Mosyakin $D$ \\ Institute of Botany, National Academy of Sciences of Ukraine, 01004 Kyiv, Ukraine; \\ inst@botany.kiev.ua or s_mosyakin@hotmail.com \\ * Correspondence: elizabeth.kordym@gmail.com
}

Received: 29 April 2020; Accepted: 29 June 2020; Published: 3 July 2020

check for updates

\begin{abstract}
Modern ideas about the role of epigenetic systems in the regulation of gene expression allow us to understand the mechanisms of vital activities in plants, such as genomic imprinting. It is important that genomic imprinting is known first and foremost for the endosperm, which not only provides an embryo with necessary nutrients, but also plays a special biological role in the formation of seeds and fruits. Available data on genomic imprinting in the endosperm have been obtained only for the triploid endosperm in model plants, which develops after double fertilization in a Polygonum-type embryo sac, the most common type among angiosperms. Here we provide a brief overview of a wide diversity of embryo sacs and endosperm types and ploidy levels, as well as their distribution in the angiosperm families, positioned according to the Angiosperm Phylogeny Group IV (APG IV) phylogenetic classification. Addition of the new, non-model taxa to study gene imprinting in seed development will extend our knowledge about the epigenetic mechanisms underlying angiosperm fertility.
\end{abstract}

Keywords: embryo sack; endosperm; genomic imprinting; phylogeny; ploidy

\section{Introduction}

The history of science convinces us that scientific thought and discoveries usually develop in a spiral pattern: at new turns, old problems acquire new levels of understanding in the light of new ideas and methodological approaches, as well as new achievements in technology, chemistry, and bioinformatics. A clear example of this is the history of the development of ideas in epigenetics. The term "epigenetics" comes from the Greek word "epigenesis" (epi = on, upon; genesis = origin). It emphasizes the widespread occurrence of the epigenetic mode of inheritance, especially among plants. Features of plant biology provide rich material for discussing the participation of epigenetic systems in gene expression regulation and inheritance in the development and adaptation of plants in ontogenesis, due to their ability to propagate vegetatively by rhizomes, runners, bulbs, tubers, and corms, as well as by plantlets emerging from plant leaves, etc. In addition, annual growth of perennial plants (presumably clones) and apomictic propagation-adventitious embryonia, aposporia, and possibly diplosporia-should be noted as well. Modern ideas regarding the epigenetic systems of regulation of gene expression by DNA methylation/demethylation, modifications of histones and chromatin, RNA interference in plant development (including the phenomena of paramutation, nucleolus domination, genomic imprinting, and gene regulation based on microRNAs), as well as the importance of epigenetic systems in plant protection and resistance against viral infection, are highlighted in numerous articles and comprehensive reviews [1-5].

Genomic imprinting (parent-of-origin-specific gene expression via epigenetics) refers to the epigenetic modification of alleles inherited by the maternal or paternal line, which leads to their different expression depending on the parent genome. Thus, the parental (maternal and paternal) genomes are not functionally equivalent due to genomic imprinting [6]. It seems remarkable that 
genomic imprinting is now reliably known in plants, in particular dicotyledons and monocotyledons [7,8], first of all, for the endosperm - a highly specialized tissue that not only provides the embryo with necessary nutrients, but also plays a special biological role in the process of formation of seeds and fruits. Although both the embryo and endosperm arise in the same system of the embryo sac after fertilization, they differ in the nature of their reactions to the influence of various factors. Morphophysiological studies of the endosperm in connection with various conditions of its occurrence and development (distant hybridization, pseudogamy, various pollination modes, or its absence) showed the versatility of its functions. Recent investigations have demonstrated that "the endosperm is perhaps the most epigenetically divergent plant tissue, with unique DNA methylation and chromatin structure features" [7]. The existence of highly complex physical and physiological relationships between extra-embryonic tissues, including the endosperm, and the developing embryo has been repeatedly emphasized [9-15].

It should be noted that the currently available data on genomic imprinting in the endosperm were only obtained in studies of the triploid endosperm formed after double fertilization in the Polygonum-type embryo sac, the most common one among angiosperms. So, in this mini-review, we would like to draw attention to the need for research into other types of endosperm, to better understand the essence and peculiarities of molecular mechanisms of seed reproduction in plants, providing biological progress of species, and in evolving biodiversity in general.

\section{Genomic Imprinting in the Embryo Sac, Mainly in the Endosperm}

For the first time, genomic imprinting, i.e., differential expression of the two alleles of the same gene depending on its parental origin, was described in plants by J.L. Kermicle [16] on the example of a maize-specific gene $R$. In subsequent years, research interest into this phenomenon was renewed after the discovery of $M E D E A$, the first imprinted gene in plants that is essential for their development $[17,18]$. Later, new imprinted genes have been revealed in the endosperm and great progress has been made in understanding the mechanisms of imprinted gene expression in a mature embryo sac and in the embryo and endosperm after fertilization [6,7,19-27]. Interesting parallels have been drawn between the mechanisms underlying genomic imprinting in plants and mammals. Therefore, we have only recently considered the modern ideas on the participation of the epigenetic systems in the regulation of imprinted genes in the embryo sac, mainly in the endosperm, and its functional significance.

The study of DNA methylation in the embryo and endosperm of wild-type Arabidopsis thaliana (L.) Heynh. (Brassicaceae/Cruciferae) demonstrated the large-scale changes in methylation accompanying endosperm development and the expression of endosperm-specific genes. Due to certain difficulties involved with the isolation of individual cells of the embryo sac, the hypothesis of differences in the epigenome of the egg and central cell has not yet been fully tested, although the presence of several imprinted genes specific to the endosperm has been proven [28-30]. Imprinting is expected to play a role in the epigenetic differentiation of the egg and central cell of an embryo sac before fertilization [6] and then between the zygote and endosperm, as well as between maternal and paternal DNA in the endosperm [7].

It was shown that an allelic copy with reduced or eliminated expression at imprinted loci had higher levels of DNA methylation in the endosperm with the expected constancy [31,32]. Determination of the allele-specific expression of the MEDEA (MEA) and FWA genes in the embryo and endosperm, carried out on the 6th day after pollination, showed $M E A$ mono-allelic expression from the mother-inherited allele both in the embryo and in the endosperm [33]. The expression of maternally inherited MEA alleles in the central cell of the embryo sac is activated by the DEMETER (DME) DNA glycosylase, which directly removes the 5-methylcytosine base and is encoded by the DEMETER (DME) gene [34], which is expressed preferentially in the central cell of an embryo sac before fertilization. It has been shown that the specificity of CG demethylation for maternal sequences is proved by the partial restoration of CG methylation in the endosperm to levels found in other tissues due to $D M E$ mutations [22,23]. DME also activates the FWA gene in the central cell prior to fertilization and is believed to play a common role in the regulation of imprinted genes [32]. Other imprinted genes 
also have cytosine methylated regions in promoters that are associated with maternally restricted expression. The imprinted expression of many genes, including MEA, FIS1, FWA, and other genes, was known to be differentially methylated in a DME-dependent manner [23]. It has been shown that the expression of the MET1 gene supports the activity of DNA methyltransferase in A. thaliana. As in the met1 mutant, DNA methylation is reduced both in repeating sequences and in a single copy [35]. MET1 has been reported to act as an antagonist to DME in controlling the expression of maternal MEA [36].

The main volume of methylation in the endosperm of $A$. thaliana wild type was lower in all sequence contexts, compared with the embryo. In the endosperm, fragments of mobile genetic elements were intensively demethylated, which was accompanied by $\mathrm{CHH}(\mathrm{H}$ is $\mathrm{A}, \mathrm{C}$, or $\mathrm{T})$ hypermethylation of mobile genetic elements into the embryo [21]. In the authors' opinion, short-term transposon activation in the endosperm is not very important, since its genome is not passed on to the next generation. DNA-dependent RNA polymerase IV (PolIV), which specializes in small RNA-mediated gene silencing pathways, was shown to be highly expressed in the endosperm and its expression is predominantly of maternal origin [37]. It is assumed that activation of transposable elements and, as a result, the production of small interfering RNAs (siRNAs) in the central cell of an embryo sac, which migrate to the egg cell and embryo, could actively contribute to an increase in methylation and silencing of mobile genetic elements in the egg cell and subsequently in the embryo via siRNA transport $[20,22,25,27]$.

An important role in the regulation of imprinted gene expression belongs to Polycomb-group (PcG) proteins, which form a protein complex of about $650 \mathrm{kDa}$ and regulate plant life cycles, usually suppressing the transcription of their target genes $[19,28,38,39]$. It is assumed that these proteins act at the level of chromatin structure to ensure mitotically inherited repression by H3K27 methylation. In $A$. thaliana, the identified genes encoding PCG proteins were generally named FERTILIZATION INDEPENDENT SEED (FIS), FERTILIZATION-INDEPENDENT ENDOSPERM (FIE), FIS2, and MULTI-COPY SUPPRESSOR OF IRA1 (MSI1). The PCG complex regulates maternally and paternally expressed genes [22]. It is assumed that the main function of the FIS PcG complex is the imprinting of paternally inherited genes in the endosperm [19]. A PHERES1 (PHE1) target gene was identified that is directly regulated by the FIS PcG protein complex [28,40]. Maternal inheritance of the FIS2, MEA (an FIS component), and FIE genes is necessary for the formation of viable seeds. The FIS PcG complex regulates dosage-sensitive genes in the endosperm [21]. An important component of $M E A$ imprinting is repression of the paternal $M E A$ allele in the endosperm; this process involves the autoregulation of MEA by H3K27 55.68.69 trimethylation [19]. FIE and MEA are proposed to interact directly in wild-type plants to control female gametophyte, endosperm, and embryo development [41]. It was demonstrated that the PHE1 flanking sequence was demethylated by DME in the central cell, which allows polycomb repressive complex 2 (PRC2) to establish a repressive chromatin environment. PHE1 imprinting is lost in the endosperm in a DME-dependent manner [23].

The PHE1 gene encodes a transcription factor of the MADS-box gene family and is usually depressed in the mea and fis mutants. MADS-box genes are also targeted by some members of the plant PcG [38]. It has been shown that PHE1 is not expressed in a female gametophyte, but its activity is found in the central cell of an embryo sac in wild-type and fis mutants one to two days after pollination. Later in the developing seed, the expression of PHE1 becomes limited in the chalazal region of the endosperm in the wild type, while in the mea and fis mutants it remains intense. It has been demonstrated that FIE and MEA proteins are associated with the proximal part of the PHE1 promoter and the beginning of the coding region [42]. As already noted, PHE1 is a direct target of FIE and MEA, and, according to the authors, this is the first serious demonstration of direct PCG targets in plants. Partial seed abortion in mea mutants is thought to be caused by PHE1 mis-regulation. Ripe seeds were not normal; they were larger, remained green longer, and were more sensitive to dehydration [42]. Currently, investigations of the role of genomic imprinting in endosperm function at the later stages of seed development are being expanded. It was demonstrated that intraspecific variations in allele-specific imprinting of the class IV 
homeodomain leucine zipper (HD-ZIP) transcription factor HDG3 in the endosperm is an important determinant of endosperm cellularization (the transfer from the stage of free nuclei to the cellular stage) and seed development phenotypes [43]. Recently, the type I MADS-box transcription factor (TF) PHE1 was reported to be a major regulator of imprinted genes and other genes relevant to endosperm development. PHE1 can establish endosperm-based reproductive barriers in crossing [44]. Regulation of imprinting is suggested to be diverse. The evolutionary and biological significance of genomic imprinting has been emphasized [45].

Very interesting data were reported by P. Khanduri et al. [46] about the disappearance of FIE expression in the flowering stage of Zeylanidium olivaceum (Gardner) Engl. and Polypleurum stylosum (Wight) J.B. Hall (the latter is now considered to be a synonym of P. wallichii (R.Br. ex Griff.) Warm.), both belonging to the family Podostemaceae (order Malpighiales, the rosids clade of eudicot angiosperms), which are submerged aquatic plants growing on rocky substrata under running water, although ZoFIE and PsFIE transcripts were present in the vegetative tissue. In the authors' opinion, the absence of double fertilization and the endosperm underlie this unique pattern of expression [46]. In the family Podostemaceae, an embryo sac is monosporic and four-celled. A chalazal nucleus degenerates at the two-nucleate stage of female gametophyte development, so the mature embryo sac contains the micropylar egg apparatus-an egg cell and two synergids and a polar nucleus. Double fertilization is absent and the endosperm does not develop. The absence of the endosperm is compensated by the nucellar plasmodium, which is located below the female gametophyte. The nucellar plasmodium begins to form at the stage of the two-nucleate embryo sac by disintegration of cell walls, and it becomes the coenocyte before the fertilization of an egg cell, for example in Inversodicraea bifurcata Engl. (now accepted as Ledermanniella bifurcata (Engl.) C.Cusset) and "I. keniensis sp. nov." (ined.) Nagendran et Sicolia [47] or during the post-fertilization period, for example in Tristicha trifaria Spreng. [48].

\section{Endosperm}

The polyploid nature of the endosperm of angiosperms was established due to the discovery of double fertilization in Lilium martagon L. by S.G. Navashin [also transliterated as Nawaschin] in 1898 [49]. Of the two sperms that the pollen tube brings to the embryo sac, one sperm fertilizes the egg cell, generating the diploid zygote, whereas the other sperm fuses with the central cell of the embryo sac, giving rise to the endosperm (Figure 1).

Discovery of double fertilization by S.G. Navashin and further demonstration of its presence in almost all angiosperm species, representing diverse evolutionary lineages, showed both the universality and uniqueness of the double fertilization phenomenon for flowering plants [50-58]. This has become one of the main arguments in favor of the monophyletic origin of this most highly organized division (mega-diverse, high-rank clade) of the plant world. It has been found that double fertilization is normally carried out in embryo sacs of all types, regardless of the number of polar nuclei fusing with the second sperm nucleus in the central cell of the embryo sac or its ploidy level. In only some species of orchid, for example in tropical Phaius blumei Lindl. (now accepted as P. tankervilleae (Banks) Blume), the sperm closely contacts with the polar nuclei, but does not fuse with them [51]. The endosperm is not formed in these species of orchids, nor is it formed in Podostemaceae species.

Viable seeds in plants with apomixis develop after fertilization of the polar nuclei in the central cell, a process known as pseudogamous apomixis. Diploid parthenogenesis (diplosporic or aposporic) takes place in such embryo sacs. Aposporic and meiotic embryo sacs can be simultaneously present in the same ovule. In single obligate apomicts, the diploid egg and the tetraploid secondary nucleus in the central cell are able to develop without fertilization [59-61]. Numerous experiments on distant hybridization convincingly demonstrated the dependence of embryogenesis on the development of the endosperm. In cases of hybrid endosperm disturbance or its absence, the development of a viable hybrid embryo stops at certain stages and can only be continued if the embryo is isolated and placed on a nutrient medium in vitro (embryo rescue techniques) [10,62-66]. Navashin's views [67] on the essence and role of double fertilization formed the basis for further ideas about the biological 
role of the endosperm in the formation of seeds and fruits. It particularly explained the occurrence of xenia in maize, a phenomenon in which kernel characteristics vary as a result of pollination of part of the maize flowers by foreign pollen ([68], p. 724).

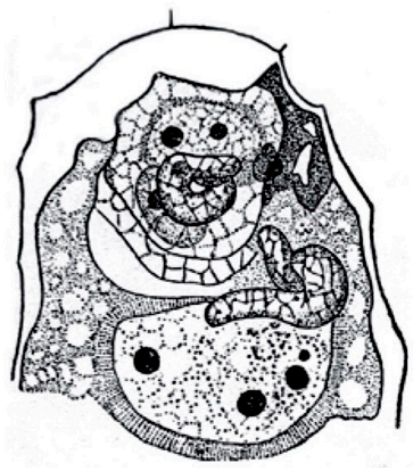

(a)

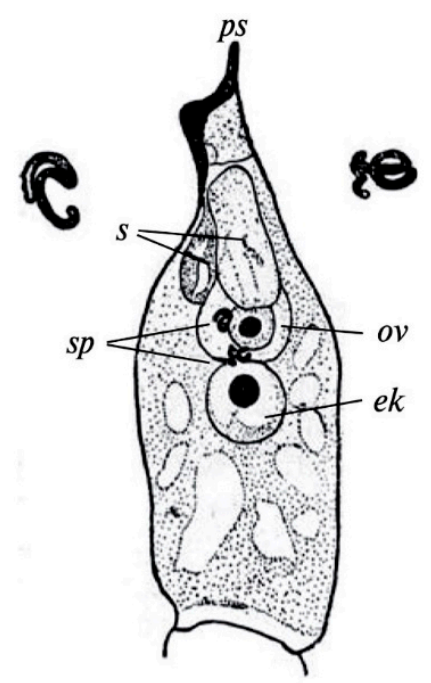

(b)

Figure 1. Double fertilization in Lilium martagon (a) and Helianthus annuus (b) [67]. ps-pollen tube, $\mathrm{s}$ - synergid, ov-egg cell, sp—sperms, ek—nucleus of the central cell of the embryo sac.

\subsection{Endosperm Types}

At present, the formation of three types of endosperm in angiosperms has been clearly established-nuclear, cellular, and helobial.

The nuclear type of endosperm is characterized by the fact that the first division of the primary nucleus of the endosperm (the fusion product of polar nuclei with a sperm) in the central cell of an embryo sac, as well as the division of its derivatives at the initial stages of seed development, result in the formation of free endosperm nuclei, which are located in the cytoplasm layer along the periphery of the embryo sac. The central part of an embryo sac is usually occupied by a vacuole. Generation of cell walls between the free nuclei in different species is carried out with an unequal number of nuclei, ranging from four to eight, or up to a thousand or more. There are variants in the endosperm's transition from the free-nuclei stage to the cellular stage, including the formation of cell walls from the periphery of an embryo sac to its center, or from the micropylar part to the basal one and vice versa, the degree of filling of the embryo sac cavity with endosperm cells, etc.

In the cellular type of endosperm, the first division of the primary endosperm nucleus in the central cell of the embryo sac and all subsequent divisions are accompanied by cytokinesis. The direction of cytokinesis during the first division of the primary endosperm nucleus can vary. A cell plate is chiefly situated in the transverse direction; a spindle is oriented longitudinally, or less often obliquely. The direction of cell wall laying during subsequent divisions also varies.

In the helobial type of endosperm, the first division of the primary endosperm nucleus in the central cell of an embryo sac is accompanied by cytokinesis, as a result of which there are two cells of unequal volume-the micropylar cell is several times larger than the basal one. In the micropylar cell, free nuclei form first, and the cell walls are laid between them later, as with the nuclear-type endosperm. The chalazal cell functions for the most part as a haustorium-mononuclear, if the cell nucleus no longer divides, or multinuclear as a result of nuclear divisions. In some cases, division of the nucleus in a chalazal cell is accompanied by cytokinesis.

According to the summary provided by G. Davis [52], the nuclear type of endosperm was described in at least 161 families of angiosperms, $83 \%$ of which are dicotyledonous (mainly eudicots, 
sensu Angiosperm Phylogeny Group IV (APG IV) [69]). The cellular endosperm type is characteristic of 79 families, almost all of which, with the exception of Araceae and Lemnaceae (two groups of monocots which are now usually merged in one family, Araceae sensu lato), belong to dicots. The helobial type is known for 17 families, of which 14 are monocots. Although for some families one endosperm type is characteristic, endosperm types vary significantly in other families, often occupying rather distant positions in the phylogenetic system. Combinations of the nuclear and cellular types are more common. For example, this was reported in families such as Alangiaceae (often included in Cornaceae sensu lato), Asclepiadaceae (now usually treated as Apocynaceae subfam. Asclepiadoideae), Asteraceae, Buxaceae, Gentianaceae, Haloragaceae, Hydrophyllaceae (now usually treated as Boraginaceae subfam. Hydrophylloideae), Lauraceae, Nymphaeaceae, Philadelphaceae (now included in Hydrangeaceae), Piperaceae, Rubiaceae, Vacciniaceae (now submerged in Ericaceae sensu lato), and Winteraceae. Nuclear and helobial types of the endosperm were described in families Agavaceae (now usually treated as Asparagaceae subfam. Agavoideae), Alismataceae, Amaryllidaceae, Hypoxidaceae, Linaceae, Spigeliaceae (now included in Loganiaceae sensu lato), Trilliaceae (now included in Melanthiaceae as tribe Parideae). Cellular and helobial types were described in families Olacaceae, Santalaceae, and Thismiaceae, and all three types of endosperm are found in families Boraginaceae and Solanaceae [70]. Species of Podostemaceae and partly Orchidaceae are devoid of double fertilization and endosperms. The subsequent stages of an endosperm's development-synthesis and accumulation of reserve nutrients, its presence in mature seeds or its resorption during the embryo maturation, etc.- do not reveal any direct connection with its type.

Endospermal haustoria are very diverse in their structure and development, especially in species with cellular and helobial endosperm types. In the nuclear type of endosperm, haustoria arise mainly from the chalazal end of the embryo sac. In most cases they are relatively short and remain at the coenocytic stage. The longest haustoria in embryo sacs with a nuclear type of endosperm are known in the families Euphorbiaceae and Cucurbitaceae. For example, haustoria reach $1000 \mu \mathrm{m}$ in length in Croton klotzschianus (Wight) Thwaites and C. sparsiflorus Morong (now usually included in C. bonplandianus Baill.). They reach $7398 \mu \mathrm{m}$ in Cucurbita pepo L. and 12,000 $\mu \mathrm{m}$ in C. ficifolia Bouché. An interesting feature of nuclear endosperm development has been described in Lomatia species of the family Proteaceae [70]. When the embryo consists of 20-30 cells, the endosperm becomes cellular in the micropylar part of an embryo sac; in the chalazal part it remains at the stage of free nuclei. Finger-like unicellular outgrowths appear on the entire surface of the endosperm and their formation increases the absorptive surface (Figure 2).
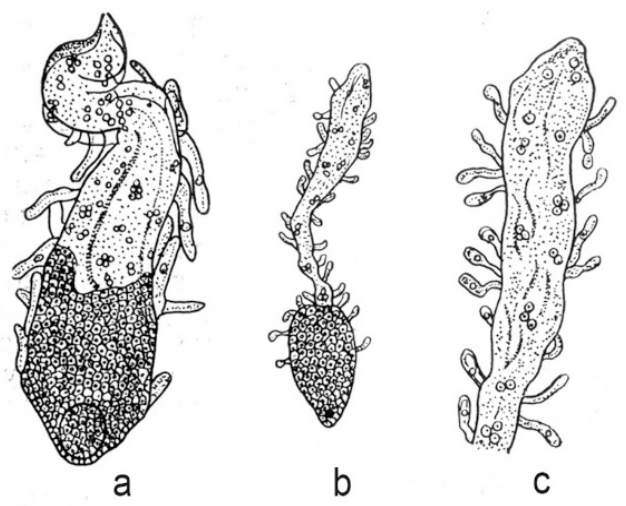

Figure 2. Endosperm and embryo in Lomatia polymorpha R.Br. (a) and L. tinctoria R.Br. $(\mathbf{b}, \mathbf{c})$ [71].

In angiosperms with cellular and helobial types of the endosperm (taxa of families Acanthaceae, Araceae, Boraginaceae, Lamiaceae, Lentibulariaceae, Lobeliaceae, Magnoliaceae, Nymphaeaceae, and Viscaceae), haustoria can arise either from the chalazal end of an embryo sac or from the micropylar end, as well as from both. In Jodina rhombifolia (Hook. et Arn.) Reissek (family Santalaceae), a haustorium is formed from a mononuclear chalazal cell [72], and only the micropylar cell gives 
rise to the endosperm itself. The nucleus of the chalazal cell migrates to the haustorium and greatly hypertrophies. Numerous branches of the free end of the haustorium give it the look of coral (Figure 3).

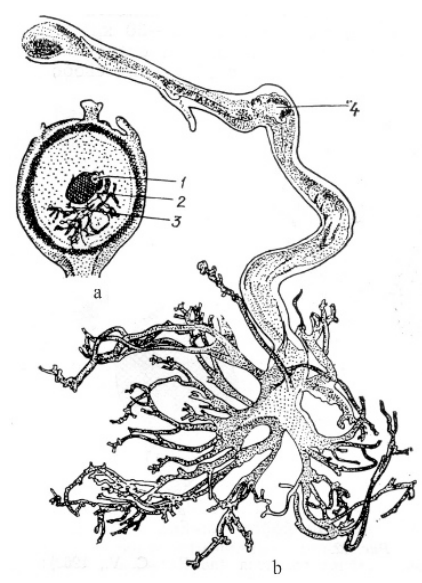

Figure 3. General view of fruit at the stage of a globular embryo (a) and haustorium (b) in Jodina rhombifolia [72]. 1-embryo, 2-endosperm, 3-haustorium, 4-nucleus.

Micropylar and chalazal endospermal haustoria are well developed in the family Loasaceae. As reported for Loasa bergii Hieronym. (now accepted as Pinnasa bergii (Hieron.) Weigend et R. H. Acuna), the chalazal haustorium is spherical in shape and usually contains one hypertrophic nucleus, although haustoria with a large number of nuclei are sometimes observed [73]. The micropylar haustorium contains free nuclei and has hyphoid-like branches reaching significant sizes (Figure 4).

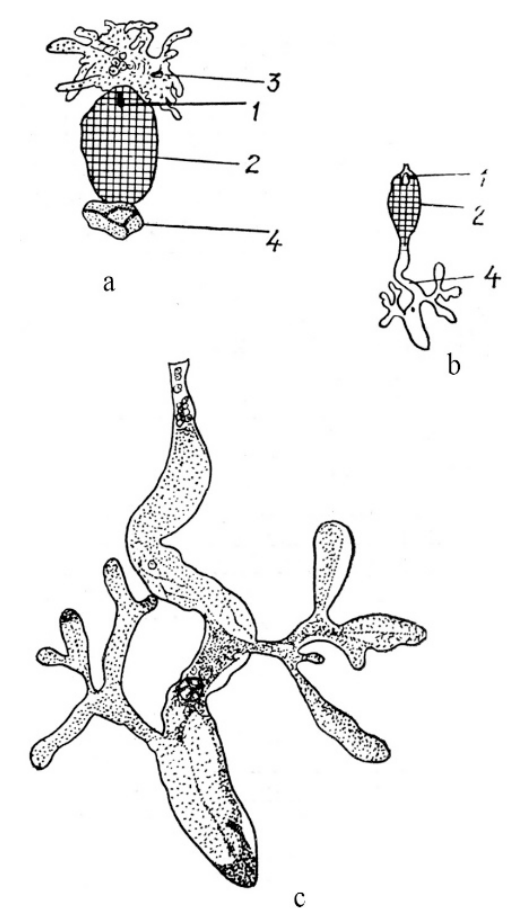

Figure 4. General view of embryo and endosperm with chalazal and micropylar haustoria in Loasa bergii (a) and with chalazal haustorium in Blumenbachia silvestris (= Caiophora silvestris) (b). (c)-fragment of Figure 4b [73]. 1-embryo, 2-endosperm, 3-micropylar haustorium, 4-chalazal haustorium.

Haustorium branches penetrate the ovule integument and funiculus, sometimes reaching the placenta. The elongated chalazal haustorium in Blumenbachia silvestris Poepp. (= Caiophora silvestris (Poepp.) Urb. et Gilg) consists of the narrow multicellular base and the highly branched 
apical part containing only one hypertrophic nucleus. The micropylar haustorium has a similar structure, but it is shorter and wider, and contains numerous nuclei, between which cell walls can form. Mentzelia laevicaulis (Douglas ex Hook.) Torr. et A.Gray is characterized by an elongated and unbranched chalazal haustorium consisting of many large cells. The micropylar haustorium is wider and shorter than the chalazal haustorium (Figure 4 b,c). In species of the family Scrophulariaceae (as understood in its traditional wide circumscription), in addition to the micropylar and chalazal haustoria, several secondary lateral haustoria can form in the endosperm micropylar and chalazal parts [50,74]. Well-developed and aggressive haustoria of all three types in some species of the family can be formed simultaneously, thus creating a very effective absorptive system.

\subsection{Embryo Sac Types and Endosperm Ploidy}

Different levels of endosperm ploidy depend on the type of embryo sac, consequently endosperm ploidy levels can vary from $2 n$ (Oenothera-type of embryo sac) to $9 n$ (Peperomia-type of embryo sac). Therefore, we briefly dwell on the classification of the types of embryo sacs and their distribution over angiosperm families. Of the proposed classifications of types of embryo sacs [75-79], we selected the main types reflecting the evolution of the female gametophyte from the monosporic type to the bi- and tetrasporic types $[50,78]$. Identification of a type of embryo sac development is based on the following three features: (1) the number of macrospores giving rise to the embryo sac; (2) the number of mitoses that occur during the development of the embryo sac; and (3) the behavior of the nuclei that determines the organization of the embryo sac.

1. Polygonum-type (normal type) is single-spore, three-mitosis. The mature embryo sac is characterized by two three-cell polar groups (egg apparatus and antipodes) and two polar nuclei in the central cell. The most variable group is formed by antipodes (rapidly degenerating, normal, hypertrophic, reproducing).

2. Oenothera-type: single-spore, two-mitosis. The mature embryo sac has only one polar group: a three-cell egg apparatus and one upper polar nucleus in the central cell.

3. Allium-type: bisporic, two-mitosis. The organization of the mature embryo sac is the same as in the normal type.

4. Drusa-type: four-spore, two-mitosis. The mature embryo sac contains a three-cell egg apparatus, 11 antipodal cells, and two polar nuclei in the central cell.

5. Fritillaria-type: four-spore, two-mitosis. Upon transition from the prophase to the metaphase of the first mitosis, the fusion of three chalazal nuclei occurs. As a result, a secondary four-nucleus embryo sac with a haploid upper and triploid lower pairs of nuclei is formed after the first mitosis. The second mitosis leads to the formation of an embryo sac with the same organization as in the normal type, but with triploid antipodal cells and the lower polar nucleus.

6. Plumbagella-type: four-spore. The organization of the mature embryo sac originating directly from the tetranuclear coenocyte is simplified. The egg apparatus consists of only one egg; the central cell contains two polar nuclei and one antipodal cell.

7. Adoxa-type: four-spore, single-mitosis. The organization of the mature embryo sac is the same as in the normal type.

8. Penaea-type: four-spore, two-mitosis. After two mitoses, four nuclei are formed at each pole. The mature embryo sac contains four polar groups of three cells each (egg apparatus, chalazal, and two lateral) and a central cell with four polar nuclei.

9. Plumbago-type: four-spore, single-mitosis. In a four-spore coenocyte, one nucleus is located in the micropylar end, the second is located in the chalazal end, and the other two occupy a lateral position. The nuclei divide, and one cell is formed near each pole. In the mature embryo sac, the micropylar cell is an egg cell. Chalazal and lateral cells usually die. The central cell contains four polar nuclei, which fuse to form a secondary tetraploid nucleus. 
10. Peperomia-type: four-spore, two-mitosis. After the first mitosis, eight nuclei are distributed usually in the peripheral layer of the cytoplasm or two of them are grouped in the micropylar end, and six are closer to the chalazal end. After the second mitosis, eight nuclei occupy the peripheral position, and the same number of nuclei is in the cell center. In the mature embryo sac there are an egg cell and a synergid in its micropylar end. Six lateral cells are close to the chalazal end of the embryo sac. Eight polar nuclei in the central cell fuse, forming the secondary nucleus (Figure 5).

Among the described variations of the main types of embryo sacs [77-80] we would like to note the organization of mature embryo sacs in Tulipa tetraphylla Regel and taxa of Tulipa subgen. Eriostemones (Boiss.) Raamsd. reported by I. D. Romanov [79]. In the mature four-spore, single-mitosis embryo sac of $T$. tetraphylla, the egg apparatus consists of five cells, the central cell with two polar nuclei, and the antipodal cell alone with a degenerating nucleus. Cells of the egg apparatus are not differentiated. A mature four-spore, single-mitosis embryo sac of Tulipa subg. Eriostemones has only one micropylar group: the egg apparatus of seven cells and the upper polar nucleus of the central cell. The egg is not morphologically indistinguishable before fertilization.

The Polygonum-type embryo sac has been found in $80 \%$ of the examined angiosperm species in 239 families out of about 295 recognized ones. The Allium-type embryo sac is characteristic for such families as Alismataceae, Datiscaceae, Malpighiaceae, Theaceae, Limnocharitaceae, Loranthaceae (subfamily Viscoideae, or a separate family Viscaceae of the order Santalales), and Liliaceae. The Adoxa-type embryo sac is described in Adoxaceae and Liliaceae families; the Drusa-type embryo sac is described in Limnanthaceae; the Oenothera-type embryo sac is described in Onagraceae; and Plumbagoand Plumbagella-types are described in Plumbaginaceae. The Peperomia-type is known in the families Euphorbiaceae and Piperaceae; the Fritillaria-type in Liliaceae; and the Penaea-type in the families Euphorbiaceae, Penaeaceae, Malpighiaceae, and Apiaceae. Of course, those are only some examples of the distribution patterns by families, because particular embryo sac types are much more widespread over the phylogenetic tree of angiosperms.

Only one type of embryo sac is characteristic for a number of families; for example, all species of the family Poaceae studied in this respect, with the exception of apomictic forms, have a Polygonum-type embryo sac. In other families and higher-rank groups, at least two different types of embryo sacs are known in one family. For example, the Polygonum-, Allium- and Adoxa-type embryo sacs are described in the families Caprifoliaceae, Caryophyllaceae, Commelinaceae, Orchidaceae, Solanaceae, and Trilliaceae (Melanthiaceae sensu lato); the Polygonum-, Allium-, Adoxa-, Drusa-, and Fritillaria-type embryo sacs are known in families Asteraceae and Liliaceae; and the Allium-, Adoxa-, Drusa-, Fritillaria-, and Penaea-type embryo sacs occur in the family Euphorbiaceae [52].

Information on distribution of embryo sac types over the phylogenetic tree of angiosperms is also available from the continuously updated Angiosperm Phylogeny Website; in particular, P.F. Stevens recognizes the following main types: Adoxa-, Allium-, Drusa-, Endymion-, Fritillaria-, Oenothera-, Penaea-, Peperomia-, Plumbagella-, Plumbago-, Polygonum-, and Schisandra-types [81].

We emphasize once again that the trophic and physiological role of the endosperm in the formation of an embryo, seed, and fruit is basically the same, regardless of the type of its development and ploidy, as shown by numerous studies of embryology and biology of the process of seed maturation in a number of cultivated angiosperms in natural and experimental conditions. Attempts to compare particular types of endosperm development with the shape and size of embryo sacs, as well as with a rate of embryo development, have not yielded positive results. 
Types of embryo sacs in angiosperms

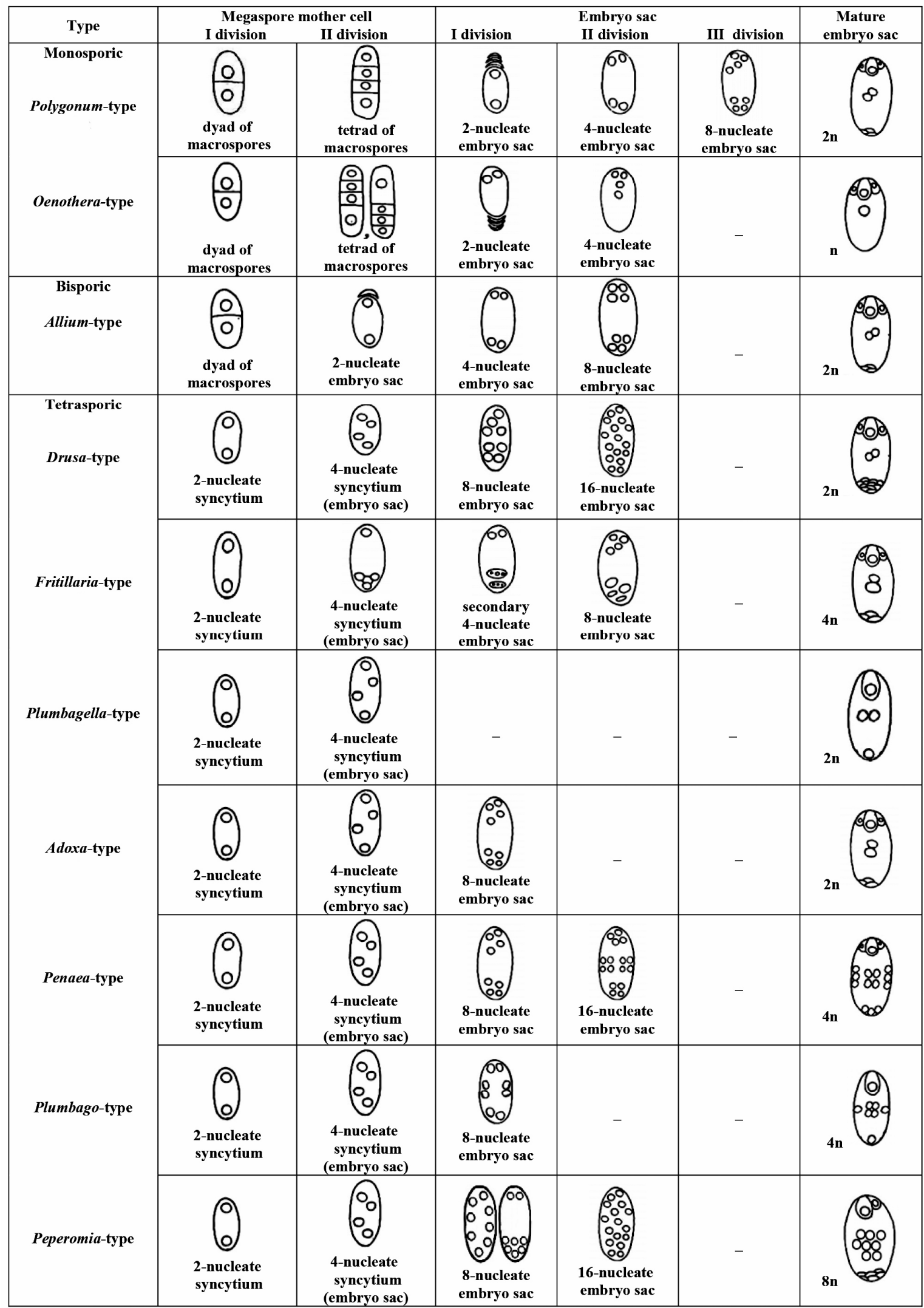

Figure 5. Types of embryo sac development in angiosperms (modified [78]). The number of chromosomes (n) in the secondary nucleus of the central cell of an embryo sac is indicated. 


\section{Embryo Sac and Endosperm Phylogeny}

The question of the origin of a female gametophyte of the angiosperms is closely connected with the problem of the origin of angiosperms (however, we do not consider this evergreen and fascinating problem in our article). The peculiarities of the angiosperm female gametophyte structure, which is not found in all other divisions of higher plants, remains unresolved and debated to date. It is sufficient to mention that the current state of botanical knowledge allows us to join the opinion repeatedly expressed in the literature that the emergence of angiosperms was the greatest arogenesis event (a progressive evolution phenomenon, in the terms of A.N. Severtzov [82] and I.I. Schmalhausen [83]) and the evolution of angiosperms proceeded in various directions with a pronounced heterochronism. In the conjugate chain of aromorphoses (roughly corresponding to the modern concept of key evolutionary innovations; see [84] and references therein) of the internal structures of the angiosperm generative organs (the appearance of specific female and male gametophytes, double fertilization and polyploid endosperm, etc.), the final stage is a polyploid endosperm formed as a result of fusion of a sperm cell with the polar nuclei of the central cell of the embryo sac. The currently accepted concept of aromorphosis $[82,83]$ includes the appearance in the body of such progressive changes that are not strictly limited to any particular environment and, thus, raising the organism to a higher level of organization, allowing it to colonize successfully new and often very distinctive and challenging habitats [83]. The attribution of female and male gametophytes in angiosperms to phenomena such as aromorphosis underlines the higher level of their organization as compared to their ancestor and/or co-existing organisms.

Based on the assumption that the embryo sac is a homolog of a female gametophyte of the gymnosperms [85-88], the archegonial hypothesis of O. Porsch [85] and M. Favre-Duchartre [88], and the gnetaceous hypothesis of F. Fagerlind [86,87] were and still are repeatedly discussed in the literature, but neither of them is universally recognized. J. Coulter [75] expressed the idea of gradual reduction of an archegonium, which begins in gymnosperms and ends in angiosperms with the complete disappearance of its wall, from which only the reproductive structure remains, an egg cell. E. Strasburger (cited in [78]) considered the elements of the angiosperm embryo sac as the initial stages of the female gametophyte development, practically before the formation of archegonia, like in Gnetum. Currently available data on the comparative morphology and embryology of Gnetum species do not give reasons to consider the organization of the female gametophyte of Gnetales as basic for an embryo sac of angiosperms, but rather as a variant of the female gametophyte from the distant past which has been preserved, which has not received further development, and which currently represents a kind of "evolutionary dead end". A clearly formulated hypothesis of the neotenic origin of the embryo sac was proposed by I. D. Romanov [79]. Differentiation of an egg cell occurs at the very early stages of the female gametophyte development, at the latest after the third division of a nucleus of the macrospore, which naturally excludes the formation of the archegonium. E. N. Gerasimova-Navashina [89] further developed these views and also considered the embryo sac as a greatly reduced female gametophyte of some earlier ancestral forms. In her opinion, general laws that govern the development and organization of any cell being in certain conditions are manifested in the evolution of an embryo sac.

The prevailing point of view is that the Polygonum-type embryo sac (monosporic, three-mitosis, eight-nucleate, seven-celled) is the initial or ancestral one, whereas the other types, which are different variations of the main type, are likely derivatives. Less common is the belief that other types of embryo sacs-for example, a four-spore 16-nucleate embryo sac-are more primitive or evolutionarily independent from the Polygonum-type. According to Modilevsky [51], mono-, bi- and tetrasporic embryo sacs have a common origin, but from the very first days of their appearance they differed by the patterns of formation, thus being peculiar and equivalent variants of one general type. This assumption is based on the presence of a four-spore female gametophyte in Gnetum gnemon L. (G. ovalifolium Poir.), as well as on the formation of 16-nucleate embryo sacs in a number of angiosperm families, for example Euphorbiaceae, among the Polygonum-type embryo sacs typical of these families. It should be noted that formation of mono-, bi- and tetrasporic embryo sacs with the dominance 
of a bisporic embryo sac can occur in different ovules of the same species, for example in Erigeron elatus Greene.

It should be also emphasized that the Polygonum-type is present in several plant families that occupy especially important positions on the phylogenetic tree of angiosperms $[69,81,90,91]$. In particular, the Polygonum-type is typical for (1) the family Amborellaceae, representing the basalmost (the most early-branching) angiosperm clade sister to the clade containing all other angiosperms; (2) other representatives of the ANA grade (orders Amborellales, Nymphaeales, and Austrobaileyales), representing the basal grade of angiosperms, although in Amborellales the embryo sac is 9-nucleate, whereas in the two other orders it is 4-nucleate; (3) the family Acoraceae (with the single genus Acorus), which forms the basalmost clade of monocots; and (4) in early-branching eudicots, such as representatives of the family Ceratophyllaceae and most taxa of the order Ranunculales (families Lardizabalaceae, Circaeasteraceae, Menispermaceae, Berberidaceae, and Ranunculaceae; in the last family the Allium-type is also known). Such predominance of the Polygonum-type in basalmost or early-branching clades of angiosperms in general, and their main clades in particular, indicates that that type was probably the ancestral one (Figure 6).

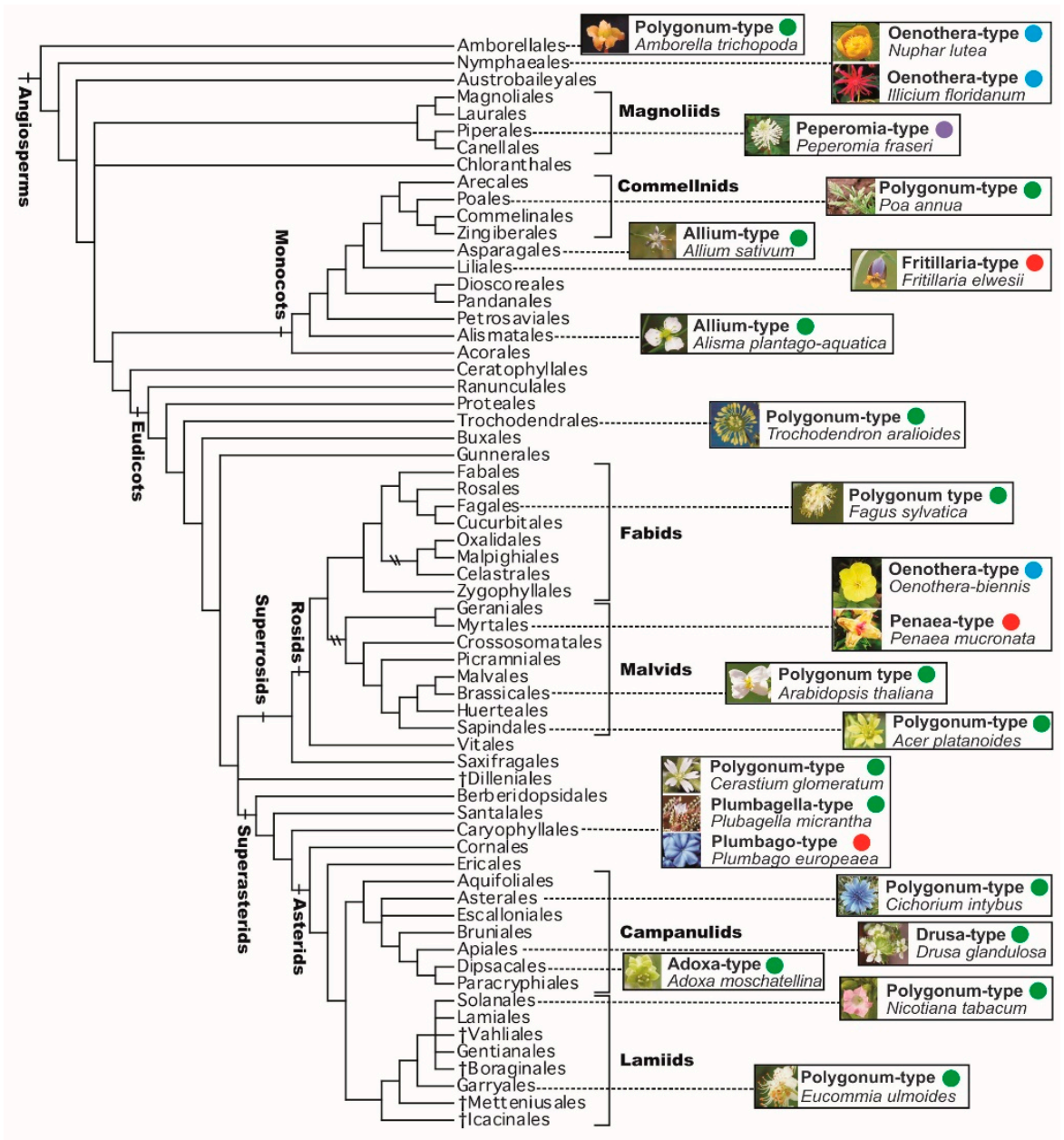

$$
\begin{aligned}
& \text { - diploid endosperm } \\
& \text { - triploid endosperm } \\
& \text { - pentaploid endosperm }
\end{aligned}
$$

Figure 6. A schematic representation (selected examples only) of the distribution of the main types of embryo sacs and, consequently, endosperm ploidy levels, through a phylogenetic tree based on Angiosperm Phylogeny Group IV (APG IV, 2016) [69]. Further details and examples are provided in the text. 
Discussion of the evolution and homology of the endosperm of angiosperms is mainly based on two alternative hypotheses. These hypotheses have been actively discussed in the past and have received new developments in connection with data from a cladistic analysis of the basal species of angiosperms, as well as from cases of fertilization of female cells with a second sperm in species of Ephedra and Gnetum [92-99]: (1) the endosperm is homologous to the embryo, i.e., it can arise from the transformation of the additional embryo development as a result of the second act of fertilization, which first occurred in the ancestors of the angiosperms; and (2) the endosperm is homologous to the female gametophyte, as a product of altered ontogenesis of female gametophytes of non-flowering seed plants, which later sexualized. In addition, a triploid endosperm could be considered homologous to the gymnosperm female gametophyte in the evolutionary context of the parental conflict hypothesis [100-102].

Two cases of penetration of two sperms from the pollen tube into the cell central of an archegonium in Ephedra nevadensis S. Watson and E. trifurca Torr. ex S. Watson were described [92,93]. One sperm fused with the egg cell, and the second with the abdominal canal nucleus, resulting in the formation of two zygotes and, as a consequence, the additional embryo. According to W. E. Friedman [94], this fact may support the point of view that the transitional stage in endosperm evolution was the formation of additional embryos with modified endosperm function to improve the developmental conditions of the sister embryo. In G. gnemon, which is characterized by the absence of archegonia [103], the fusion of each of two sperms with individual female cells in the micropylar part of the female gametophyte also described [97]. Based on these observations, the hypothesis about the origin of the gymnosperms and angiosperms from a common ancestor was revived [104-106]. Recognition of the potential homology of the reproductive traits of Gnetales and angiosperms is a key point in the hypothesis on the origin of double fertilization from their common ancestor. However, the results of modern molecular phylogenetic studies, as well as earlier morphological studies (as already mentioned), do not support these ideas, but indicate that Gnetales are a monophyletic group closely related to conifers $[107,108]$. It should also be noted that formation of a second zygote is a result of additional fertilization in Gnetales. Both zygotes give rise to identical multicellular embryos, which can be considered a phenomenon of polyembryony.

Features of the origin and genetic constitution of the endosperm of gymnosperms and angiosperms do not give reasons to consider them homologous formations, although the function of the latter after fertilization is the same. In gymnosperms, the endosperm is a vegetative cell of the female gametophyte, the development of which begins with the germination of macrospores. It is basically composed of haploid cells. The development of the endosperm of angiosperms occurs, as a rule, only after triple fusion, i.e., the fusion of sperm with the polar nuclei of the central cell of an embryo sac, resulting in the formation of the primary nucleus of the endosperm.

The accumulation of reserve substances in the endosperm of gymnosperms begins, as in angiosperms, during embryogenesis. Therefore, we can clearly observe similarity between the endosperm of angiosperm plants and the female gametophyte of gymnosperms in the process of seed maturation, but not as any evidence of their homology. Moreover, convergence takes place mainly at the level of tissues and cells that are functionally similar.

On the basis of a cladistic analysis, the possible primacy of a diploid endosperm, which is formed after fusion of a sperm with a haploid nucleus in the central cell of four-celled embryo sacs in species of Nuphar (Nymphaeaceae) and Illicium (Illiciaceae), both belonging to basal angiosperms, is discussed [98]. Based on these data, the four-celled female gametophyte, and thus the diploid endosperm, can be considered ancestral to the seven-celled female gametophyte and triploid endosperm [109]. At the same time, a monosporic seven-celled embryo sac of Polygonum-type, characteristic of most species of angiosperms, was found in the basalmost angiosperm Amborella trichopoda Baill. (Amborellaceae) [110]. We can add that the monosporic four-celled embryo sac, described in species of Nuphar and Illicium, is typical of the Oenothera-type of embryo sac inherent to the family Onagraceae (Figure 6). 
Currently, the possibility of a twofold occurrence of diploid endosperm from the initial triploid one in different clades is considered. Phylogenetic patterns of the emergence of the triploid endosperm, once in Amborella with a seven-cell embryo sac and once in a common ancestor of monocots, magnoliids, and eudicots, is widely discussed [111]. The triploid endosperm is also assumed to emerge only once in the whole evolutionary history of flowering plants, if the Polygonum-type embryo sac is recognized as being peculiar to the last common ancestor of all angiosperms. At the same time, the occurrence of bisporic and tetrasporic embryo sacs and, consequently, higher-ploidy endosperms could have emerged more than once, or even many times [80].

Thus, the question of the origin of the female gametophyte and endosperm of the angiosperms remains open, and numerous hypotheses about the initial or ancestral type of the embryo sac and endosperm, and their derivatives in the extant angiosperms, are largely debatable. The main difficulty in covering these issues lies primarily in the absence of paleobotanical data concerning the various stages of the formation of generative organs in higher plants. Therefore, in assessing the phylogenetic value of traits, subjective elements depending both on the state of scientific knowledge in a certain period and on the views of a researcher will inevitably manifest themselves. Concerns were expressed about the existence of a "vicious circle" in assessing the primitiveness or progressiveness of morphological (in the broad sense of the word) traits: certain traits are considered to be an indicator of primitive initial organization, depending on the position of the organism in a phylogenetic system, yet at the same time, the position of the organism in the currently accepted system is determined by these same traits. Cladistics and molecular phylogenetic approaches do not eliminate completely the existing difficulties, although they allow for the discussion of the "old" problems from new, much improved positions. Broadening the boundaries of knowledge and confirming or denying what has been achieved inevitably raises new discussion issues in such a complex problem as the history and evolution of the unique features of the generative organs in angiosperms.

\section{Concluding Remarks}

Current research on genomic imprinting in the endosperm has considerably expanded our understanding of its biological role in seed and fruit development, and has also created new possibilities to study molecular and genetic mechanisms involved in endosperm formation and functioning. However, it should be noted that available data have been obtained only in studies of the triploid endosperm formed after double fertilization in the Polygonum-type embryo sac, the most common type among angiosperms.

Summing up the research on gene imprinting in the endosperm, M. Gehring and P.R. Satyaki [7] outlined most topical questions which are still outstanding. Among them, we would like to emphasize the issues related to "the exact mechanisms by which imprinted genes and genome dosage regulate endosperm cellularization timing". The wide spectrum of endosperm types and ploidy levels pose great opportunities to solve these questions and to analyze the other parent-of-origin effects. A ratio of paternal and maternal genetic information after double fertilization, i.e., "gene dosage" and subsequent transcript abundance in the endosperm must change significantly as its ploidy alters. Variations of the endosperm ploidy from the $3 n$ to $2 n$ (embryo sac of Oenothera-type) and on the contrary to $5 n$ (embryo sac of Plumbago-type) and 9n (embryo sac of Peperomia-type) can be the excellent objects for testing the parental (kinship) conflict model [93] and a dosage-sensitive regulatory model [112,113]. Using such objects also provides new approaches to understanding the complex relations of the endosperm with the embryo, in particular the possible "defense" role of the endosperm in the silencing of transposons in the embryo via transport of siRNA formed as a result of intensive demethylation of mobile genetic elements in the endosperm after fertilization. In addition, it is of interest to study the DNA methylation/demethylation of imprinted genes in aposporic and diplosporic embryo sacs after fertilization of only the polar nuclei (pseudogamy), i.e., the relations of a parthenogenetic embryo (maternal origin) and endosperm (maternal and paternal origin). The comparative investigations of spatial nuclear organization in endosperms of nuclear, cellular and helobial types at the successive 
stages of their development, including the formation of endospermal haustoria, could be useful in answering the question of how the spatial nuclear organization of endosperm chromatin relates to gene imprinting [7]. Understanding the role of genomic imprinting in post-zygotic incompatibility associated with abnormal development of the endosperm under self-fertilization of cross-pollinated plants and distant hybridization, i.e., interspecific crosses, may be continued in studies of wild species with endosperms of various ploidy levels. Finally, an answer may be obtained to the question of whether the ploidy of endosperms above $3 \mathrm{n}$ is an adaptive advantage or an "excess" of development.

In general, the addition of new non-model taxa to study gene imprinting in the embryo sac before and especially after fertilization will extend our knowledge about the parent-of-origin effects in seed development in angiosperm species occupying different places in the system and the epigenetic mechanisms underlying plant seed reproduction on the whole.

Author Contributions: Conceptualization, idea of the review, E.L.K.; methodology, data analysis, E.L.K.; writing-original draft preparation, main text, E.L.K.; writing-phylogenetic aspects of the study and taxonomy/nomenclature, S.L.M.; writing-review and editing, E.L.K., S.L.M.; project administration, E.L.K. All authors have read and agreed to the published version of the manuscript.

Funding: This research received no external funding. Basic funding for both authors was provided by the National Academy of Sciences of Ukraine.

Conflicts of Interest: The authors declare no conflict of interest.

\section{References}

1. Leyser, O.; Day, S. Mechanisms in Plant Development; Wiley-Blackwell: Padstow, UK, 2003.

2. Grant-Downton, R.T.; Dickinson, H.G. Epigenetics and its implications for plant biology. 1. The epigenetic network in plants. Ann. Bot. 2005, 96, 1143-1164. [CrossRef] [PubMed]

3. Henderson, J.R.; Jacobsen, S.E. Epigenetic inheritance in plants. Nature 2007, 447, 418-424. [CrossRef] [PubMed]

4. Zhang, X. The epigenetic landscape of plants. Science 2008, 320, 489-492. [CrossRef]

5. Meyer, P. Epigenetic variation and environmental change. J. Exp. Bot. 2015, 66, 3541-3548. [CrossRef] [PubMed]

6. Grossniklaus, U. Genomic imprinting in plants: A predominantly maternal affair. Annu. Plant Rev. 2005, 19, 174-200. [CrossRef]

7. Gehring, M.; Satyaki, P.R. Endosperm etand imprinting, inextricably linked. Plant Physiol. 2017, 173, $143-154$. [CrossRef] [PubMed]

8. Hornslien, K.S.; Miller, J.R.; Grini, P.E. Regulation of parent-of-origin allelic expression in the endosperm. Plant Physiol. 2019, 180, 1498-1519. [CrossRef]

9. Modilevsky, Y.S. Embryology of Angiosperms; Ukr. SSR Acad. Sci. Publ. House: Kyiv, Ukraine, 1953. (In Russian)

10. Khudyak, M.I. Endosperm of Angiosperm Plants; Ukr. SSR Acad. Sci. Publ. House: Kyiv, Ukraine, 1963. (In Russian)

11. Oneal, E.; Willis, J.H.; Franks, R.G. Disruption of endosperm development is a major cause of hybrid seed inviability between Mimulus guttatus and M. nudatus. New Phytol. 2016, 210, 1107-1120. [CrossRef]

12. Yuan, J.; Chen, S.; Jiao, W.; Wang, L.; Wang, L.; Ye, W.; Lu, J.; Hong, D.; You, S.; Cheng, Z.; et al. Both maternally and paternally imprinted genes regulate seed development in rice. New Phytol. 2017, 216, 373-387. [CrossRef]

13. Li, J.; Berger, F. Endosperm: Food for humankind and fodder for scientific discoveries. Plant Physiol. 2012, 195, 290-305. [CrossRef]

14. Hands, P.; Rabiger, D.S.; Koltunow, A. Mechanisms of endosperm initiation. Plant Reprod. 2016, $29,215-225$. [CrossRef]

15. Ingram, G.C. Family plot: The impact of the endosperm and other extra-embryonic seed tissues on angiosperm zygotic embryogenesis. F1000Research 2020, 9. [CrossRef] [PubMed]

16. Kermicle, J.L. Dependence of the R-mottled aleurone phenotype in maize on mode of sexual transmission. Genetics 1970, 66, 69-85. [PubMed] 
17. Grossniklaus, U.; Vielle-Calzada, J.P.; Hoeppner, M.A.; Gagliano, W.B. Maternal control of embryogenesis by MEDEA, a Polycomb group gene in Arabidopsis. Science 1998, 280, 446-450. [CrossRef] [PubMed]

18. Kinoshita, T.; Yadegari, R.; Harada, J.J.; Goldberg, R.B.; Fischer, R.L. Imprinting of the MEDEA polycomb gene in the Arabidopsis endosperm. Plant Cell 1999, 11, 1945-1952. [CrossRef] [PubMed]

19. Köhler, C.; Makarevich, G. Epigenetic mechanisms governing seed development in plants. EMBO Rep. 2007, 7, 1223-1227. [CrossRef] [PubMed]

20. Gehring, M.; Bubb, K.L.; Henikoff, S. Extensive demethylation of repetitive elements during seed development underlies gene imprinting. Science 2009, 324, 1447-1451. [CrossRef]

21. Gehring, M. Genomic imprinting: Insights from plants. Annu. Rev. Genet. 2013, 47, 187-208. [CrossRef]

22. Hsieh, T.F.; Ibarra, C.A.; Silva, P.; Zemach, A.; Eshed-Williams, L.; Fischer, R.L.; Zilberman, D. Genome-wide demethylation of Arabidopsis endosperm. Science 2009, 324, 1451-1454. [CrossRef]

23. Hsieh, T.F.; Shin, J.; Uzawa, R.; Silva, P.; Cohen, S.; Bauer, M.J.; Hashimoto, M.; Kirkbride, R.C.; Harada, J.J.; Zilberman, D.; et al. Regulation of imprinted gene expression in Arabidopsis endosperm. Proc. Natl. Acad. Sci. USA 2011, 108, 1755-1762. [CrossRef]

24. Köhler, C.; Weinhofer-Molisch, I. Mechanisms and evolution of genomic imprinting in plants. Heredity 2010, 105, 57-63. [CrossRef] [PubMed]

25. Van Ex, F.; Jacob, Y.; Martienssen, R.A. Multiple roles for small RNAs during plant reproduction. Curr. Opin. Plant Biol. 2011, 14, 588-593. [CrossRef] [PubMed]

26. Huh, J.H.; Rim, H.J. DNA Demethylation and Gene Imprinting in Flowering Plants. In Epigenetic Memory and Control in Plants; Grafi, G., Ohad, N., Eds.; Springer: Berlin/Heidelberg, Germany, 2013; pp. 201-232.

27. Köhler, C.; Lafon-Placette, C. Evolution and function of epigenetic processes in the endosperm. Front. Plant Sci. 2015. [CrossRef] [PubMed]

28. Köhler, C.; Page, D.R.; Cagliardini, V.; Grossniklaus, U. The Arabidopsis thaliana MEDEA Polycomb group protein controls expression of PHERES1 by parental imprinting. Nat. Genet. 2005, 37, 28-30. [CrossRef]

29. Hsieh, P.H.; He, S.; Buttress, T.; Gao, H.; Couchman, M.; Fischer, R.L.; Zilberman, D.; Feng, X. Arabidopsis male sexual lineage exhibits more robust maintenance of CG methylation than somatic tissues. Proc. Natl. Acad. Sci. USA 2016, 113, 15132-15137. [CrossRef]

30. Kim, M.Y.; Ono, A.; Scholten, S.; Kinoshita, T.; Zilbermana, D.; Okamoto, T.; Fischera, R.L. DNA demethylation by ROS1a in rice vegetative cells promotes methylation in sperm. Proc. Natl. Acad. Sci. USA 2019, 116, 9652-9657. [CrossRef]

31. Gehring, M.; Choi, Y.; Fischer, L.R. Imprinting and seed development. Plant Cell 2004, 16, 203-213. [CrossRef]

32. Kinoshita, T.; Miura, A.; Choi, Y.; Kinoshita, Y.; Cao, X.; Jacobsen, S.E.; Fischer, R.L.; Kakutani, T. One-way control of FWA imprinting in Arabidopsis endosperm by DNA methylation. Science 2004, 303, 521-523. [CrossRef]

33. Page, D.R. Maternal Effects during Seed Development: An Expression Analysis of the FERTILIZATION INDEPENDED SEED (FIS) Class Gene MEDEA and a Search for New fis Class Mutants. Ph.D. Thesis, University of Zurich, Zurich, Switzerland, 2004.

34. Choi, Y.; Gehring, M.; Johnson, L.; Hannon, M.; Harada, J.J.; Goldberg, R.B.; Jacobsen, S.E.; Fischer, R.L. DEMETER, a DNA glycosylase domain protein, is required for endosperm gene imprinting and seed viability in Arabidopsis. Cell 2002, 110, 33-42. [CrossRef]

35. Kankel, M.W.; Ramsey, D.E.; Stokes, T.L.; Flowers, S.K.; Hang, J.R.; Jeddeloh, J.A.; Riddle, N.C.; Verbsky, M.L.; Richards, E.J. Arabidopsis MET1 cytosine methyltransferase mutants. Genetics 2003, 163, 1109-1122. [CrossRef]

36. Xiao, W.; Gehring, M.; Choi, Y.; Margossian, L.; Pu, H.; Harada, J.J.; Goldberg, R.B.; Pennel, R.I.; Fischer, R.L. Imprinting of a MEA Polycomb gene is controlled by antagonism between METI methyltransferase and DME glycosylase. Dev. Cell 2003, 5, 891-901. [CrossRef]

37. Mosher, R.A.; Melnyk, C.W.; Kelly, K.A.; Dunn, R.M.; Studholme, D.J.; Baulcombe, D.C. Uniparental expression of PolIV-dependent siRNAs in developing endosperm of Arabidopsis. Nature 2009, 460, 283-286. [CrossRef] [PubMed]

38. Goodrich, J.; Tweedie, S. Remembrance of things past chromatin remodeling in plant development. Annu. Rev. Cell Dev. Biol. 2002, 18, 707-746. [CrossRef] [PubMed]

39. Schubert, D.; Goodrich, J. Plant epigenetics: MEDEA's children take centre stage. Curr. Biol. 2003, 13, 638-640. [CrossRef] 
40. Köhler, C.; Grossniklaus, U. Epigenetic inheritance of expression states in plant development: The role of Polycomb group proteins. Curr. Opin. Cell Biol. 2002, 74, 773-779. [CrossRef]

41. Yadegari, R.; Knoshita, T.; Lotan, O.; Cohen, G.; Katz, A.; Choi, Y.; Katz, A.; Nakashima, K.; Harada, J.J.; Goldberg, R.B.; et al. Mutations in the FIE and MEA genes that encode interacting polycomb proteins cause parent-of-origin effects on seed development by distinct mechanisms. Plant Cell 2000, 12, 2367-2382. [CrossRef] [PubMed]

42. Köhler, C.; Hennig, L.; Spillane, C.; Pien, S.; Gruissem, W.; Grossniklaus, U. The Polycomb-group protein MEDEA regulates seed development by controling expression of the MADS-box gene PHERES1. Genes Dev. 2003, 17, 1540-1553. [CrossRef]

43. Pignatta, D.; Novitzky, K.; Satyaki, P.R.V.; Gehring, M. A variably imprinted epiallele impacts seed development. PLoS Genet. 2018. [CrossRef]

44. Batista, R.A.; Moreno-Romero, J.; Qiu, Y.; van Boven, J.; Santos-González, J.; Figueiredo, D.D.; Köhler, C. The MADS-box transcription factor PHERES1 controls imprinting in the endosperm by binding to domesticated transposons. ELife 2019, 8, e50541. [CrossRef]

45. Chen, C.; Li, T.; Zhu, S.; Liu, Z.; Shi, Z.; Zheng, X.; Chen, R.; Huang, J.; Shen, Y.; Luo, S.; et al. Characterization of imprinted genes in rice reveals conservation of regulation and imprinting with other plant species. Plant Physiol. 2018. [CrossRef]

46. Khanduri, P.; Sharma, R.; Bhat, V.; Tandon, R. Isolation, expression and evolution of FERTILIZATION INDEPENDENT ENDOSPERM homologs in Podostemaceae. J. Plant Res. 2016, 129, 241-250. [CrossRef] [PubMed]

47. Sicolia, S.; Onyango, J.C. Female gametopyte in two Kenyan species of Inversodicraea (Podostomaceae). Res. J. Bot. 2009, 4, 29-39. [CrossRef]

48. Sikolia, S.; Ochora, P. Female gametophyte in Tristichoideae (Podostemaceae): Re-Investigation. J. Biol. Sci. 2008, 8, 1158-1165. [CrossRef]

49. Nawaschin, S. Resultate einer Revision des Befruchtungsvorgänger bei Lilliun martagon und Fritillaria tenella. Bul. l'Académie Imp. St. Petersbourg 1898, 9, 1-6.

50. Maheshwari, P. An Introduction to the Embryology of Angiosperms; McGraw Hill Book Co: New York, NY, USA, 1950.

51. Modilevsky, Y.S. Apomixis in angiosperm plants. Ukr.SSR Bot. J. 1948, 5, 311-321. (In Ukrainian)

52. Davis, G.L. Systematic Embryology of the Angiosperms; Wiley: New York, NY, USA, 1966.

53. Poddubnaya-Arnoldi, V.A. Characteristics of Angiosperm Plant Families on Embryological Traits; Nauka: Moscow, Russia, 1982. (In Russian)

54. Jensen, W.A. Double fertilization: A personal view. Sex. Plant Reprod. 1998, 11, 1-5. [CrossRef]

55. Erdelská, O.; Dubová, J. Double fertilization of angiosperms 1899-2000. Biologia 2000, 55, 311-319.

56. Koul, A.K. Double fertilization: Changing frontiers. Phytomorphology 2001, 51, 237-250.

57. Raghavan, V. Some reflections on double fertilization, from its discovery to the present. New Phytol. 2003, 159, 565-583. [CrossRef]

58. Bleckmann, A.; Alter, S.; Dresselhaus, T. The beginning of a seed: Regulatory mechanisms of double fertilization. Front. Plant Sci. 2014. [CrossRef]

59. Asker, S.E.; Jerling, L. Apomixis in Plants; CRC Press: Boca Raton, FL, USA, 1992; p. 298.

60. Naumova, T.N. Apomixis in Angiosperms. Nucellar and Integumentary Embryony; CRC Press: Boca Raton, FL, USA, 1993.

61. Naumova, T.N. Apomixis and amphimixis in flowering plants. Cytol. Genet. 2008, 3, 51-63. (In Russian) [CrossRef]

62. Kuligowska, K.; Lütken, H.; Christensen, B.; Skovgaard, I.; Linde, M.; Winkelmann, T.; Müller, R. Evaluation of reproductive barriers contributes to the development of novel interspecific hybrids in the Kalanchoë genus. BMC Plant Biol. 2015, 15, 15. [CrossRef] [PubMed]

63. Florez-Rueda, A.M.; Paris, M.; Schmidt, A.; Widmer, A.; Grossniklaus, U.; Städler, T. Genomic imprinting in the endosperm is systematically perturbed in abortive hybrid tomato seeds. Mol. Biol. Evol. 2016, 33, 2935-2946. [CrossRef] [PubMed]

64. Kausch, A.P.; Tilelli, M.; Hague, J.; Heffelfinger, C.; Cunha, D.; Moreno, M.; Dellaporta, S.L.; Nelson, K. In situ embryo rescue for generation of wide intra- and interspecific hybrids of Panicum virgatum L. Plant Biotechnol. J. 2016, 14, 2168-2175. [CrossRef] [PubMed] 
65. Lafon-Placette, C.; Johannessen, I.M.; Hornslien, K.S.; Alia, M.F.; Bjerkanb, K.N.; Bramsiepeb, J.; Glöckleb, B.M.; Reberniga, C.A.; Brystingc, A.; Grinib, P.E.; et al. Endosperm-based hybridization barriers explain the pattern of gene flow between Arabidopsis lyrata and Arabidopsis arenosa in Central Europe. Proc. Natl. Acad. Sci. USA 2017, 114, E1027-E1035. [CrossRef]

66. Ballesfin, M.L.E.; Vinarao, R.B.; Ricky, B.; Sapin, J.; Kim, S.-R.; Jena, K.K. Development of an intergeneric hybrid between Oryza sativa L. and Leersia perrieri (A. Camus) Laurnet. Breed. Sci. 2018. [CrossRef]

67. Navashin, S.G. Selected Works; USSR Acad. Sci. Publ. House: Moscow-Leningrad, Russia, 1951. (In Russian)

68. Denney, J.O. Xenia includes metaxenia. HortScience 1992, 27, 722-728. [CrossRef]

69. Chase, M.W.; Christenhusz, M.J.M.; Fay, M.F.; Byng, J.W.; Judd, W.S.; Soltis, D.E.; Mabberley, D.J.; Sennikov, A.N.; Soltis, P.S.; Stevens, P.F.; et al. An update of the Angiosperm Phylogeny Group classification for the orders and families of flowering plants: APG IV. Bot. J. Linnean Soc. 2016, 181, 1-20. [CrossRef]

70. Modilevsky, Y.S. Cytoembryology of Angiosperms; Ukr. SSR Acad. Sci. Publ. House: Kyiv, Ukraine, 1963. (In Russian)

71. Rao, C.V. Morphology and embryology of Lomatia Br. wih a discussion its probable origin. In Plant Embryology — A Symposium; Council of Scientific and Industrial Research: New Delhi, India, 1962; pp. 261-273.

72. Bhatnagar, S.P.; Sabharwal, G. Female gametophyte and endosperm of Jodina rhombifolia Hook. Phytomorphology 1966, 10, 588-591.

73. Garcia, V. Embryological studies on the Loasaceae with special reference to the endosperm haustoria. In Plant Embryology - A Symposium; Council of Scientific and Industrial Research: New Delhi, India, 1962; pp. 157-161.

74. Aphanasyeva, N.G. Endosperm haustoria and their significance for understanding a Veronica L. genus. Bot. J. 1971, 56, 215-229. (In Russian)

75. Coulter, J.M. Relation of megaspores to embryo sacs in angiosperms. Bot. Gaz. 1908, 45, 361-366. [CrossRef]

76. Chiarugi, A. Il gametofito femmineo delle angiosperme nei suoi vari tipi di costruzione e di sviluppo. Nuovo G. Bot. Ital. 1927, 34, 1-133.

77. Schnarf, K. Contemporary understanding of embryo sac development among Angiosperms. Bot. Rev. 1936, 2, 565-585. [CrossRef]

78. Maheshwari, P.A. Critical review of the types of embryo sacs in angiosperms. New Phytol. 1937, 36, $359-417$. [CrossRef]

79. Romanov, I.D. Types of embryo sac development in angiosperm plants. In Problems of Embryology; Nauk. Dumka: Kyiv, Ukraine, 1971; pp. 72-113. (In Russian)

80. Friedman, W.E.; Madrid, E.N.; Williams, J.H. Origin of the fittest and survival of the fittest: Relating female gametophyte development to endosperm genetics. Int. J. Plant Sci. 2008, 169, 79-92. [CrossRef]

81. Stevens, P.F. Angiosperm Phylogeny Website. Version 14, 2017. Available online: http://www.mobot.org/ MOBOT/research/APweb (accessed on 21 June 2020).

82. Severtzov, A.N. The Main Directions of Evolutionary Process; BiomedGIZ: Moscow-Leningrad, Russia, 1934; pp. 1-150. (In Russian)

83. Schmalhausen, I.I. Ways and Patterns of the Evolutionary Process; USSR Acad. Sci. Publ. House: Moscow-Leningrad, Russia, 1940. (In Russian)

84. Doyle, J.A. Phylogenetic analyses and morphological innovations in land plants. Annu. Plant Rev. 2013, 45, 1-50. [CrossRef]

85. Porsch, O. Versuch einer phylogenetischen Erklärung des Embryosackes und doppelter Befruchtung der Angiospermen; Gustav Fisher: Jena, Germany, 1907.

86. Fagerlind, F. Der tetrasporische Angiospermen Embryosack und dessen Bedeutung für das Verständnis des Entwicklungsmechanik und Phylogenie des Embryosackes. Ark. Bot. 1944, 31A, 1-71.

87. Fagerlind, F. Strobilus und Blüte von Gnetum und die Möglichkeit, aus ihrer Struktur den Blütenbau der Angiospermen zu deuten. Ark. Bot. 1946, 33A, 1-57.

88. Favre-Duchartre, M. Interprétation de la reproduction sexuée des Angiospermes a la lumiére d'organisation gametophytiqus et embryonnaires d'autre Archegoniates. Phytomorphology 1971, 21, 353-361.

89. Gerasimova-Navashina, E.N. Embryo sac development, double fertilization and a question on angiosperms origin. Bot. J. 1954, 39, 655-681. (In Russian)

90. Cole, T.C.H.; Hilger, H.H.; Stevens, P. Angiosperm phylogeny poster (APP)—Flowering plant systematics, 2019. PeerJ Prepr. 2019, 7, e2320v6. [CrossRef] 
91. Soltis, P.S.; Folk, R.A.; Soltis, D.E. Darwin review: Angiosperm phylogeny and evolutionary radiations. Proc. R. Soc. B Biol. Sci. 2019, 286. [CrossRef]

92. Friedman, W.E. Sexual reproduction in Ephedra nevaliensis (Ephedraceae): Further evidence of double fertilization in a non-flowering seed plant. Am. J. Bot. 1990, 77, 1582-1598. [CrossRef]

93. Friedman, W.E. Double fertilization in non-flowering seed plants and its relevance to the origin of flowering plants. Int. Rev. Cytol. 1992, 140, 319-355. [CrossRef]

94. Friedman, W.E. Organismal duplication, inclusive fitness theory, and altruism understanding the evolution of endosperm and the angiosperm reproductive syndrome. Proc. Natl. Acad. Sci. USA 1995, 92, 3913-3917. [CrossRef] [PubMed]

95. Lopes, M.A.; Larkins, B.A. Endosperm origin, development, and function. Plant Cell 1993, 5, $1383-1399$. [CrossRef]

96. Carmichael, J.S.; Friedman, W.E. Double fertilization in Gnetum gnemon: The relationship between the cell cycle and sexual reproduction. Plant Cell 1995, 7, 1975-1988. [CrossRef] [PubMed]

97. Carmichael, J.S.; Friedman, W.E. Double fertilization in Gnetum gnemon (Gnetaceae): Its bearing on the evolution of sexual reproduction within the Gnetales and the Anthophyte clade. Am. J. Bot. 1996, 83, 767-780. [CrossRef]

98. Williams, J.H.; Friedman, W.E. Identification of diploid endosperm in an early angiosperm lineage. Nature 2002, 415, 522-526. [CrossRef]

99. Baroux, C.; Spillane, C.; Grossniklaus, U. Evolutionary origins of the endosperm in flowering plants. Genome Biol. 2002, 3. [CrossRef]

100. Haig, D.; Westoby, M. Parent-specific gene expression and the triploid endosperm. Am. Nat. 1989, 134, 147-155. [CrossRef]

101. Haig, D. Kin conflict in seed development: An interdependent but fractious collective. Annu. Rev. Cell Dev. Biol. 2013, 29, 189-211. [CrossRef]

102. Tuteja, R.; McKeown, P.C.; Ryan, P.; Morgan, C.C.; Donoghue, M.T.A.; Downing, T.; O'Connell, M.J.; Spillane, C. Paternally expressed imprinted genes under positive Darwinian selection in Arabidopsis thaliana. Mol. Biol. Evol. 2019, 36, 1239-1253. [CrossRef] [PubMed]

103. Vasil, V. Morphology and embryology of Gnetum. Phytomorphology 1959, 9, 167-215.

104. Friedman, W.E.; Carmichael, J.S. Double fertilization in Gnetales: Implication for understanding reproductive diversification among seed plants. Int. J. Plant Sci. 1996, 157, 77-94. [CrossRef]

105. Friedman, W.E. The evolution of double fertilization and endosperm: An "historical" perspective. Sex. Plant Reprod. 1998, 11, 6-16. [CrossRef]

106. Dumas, C.; Friedman, W.E. Developmental and evolutionary hypotheses for the origin of double fertilization and endosperm. C. R. Acad. Sci. III Sci. Vie 2001, 324, 559-567. [CrossRef]

107. Chaw, S.M.; Parkinson, C.I.; Cheng, Y.; Vincent, T.M.; Palmer, J.D. Seed plant phylogeny inferred from all three plant genomes: Monophyly of extant gymnosperms and origin of Gnetales from conifers. Proc. Natl. Acad. Sci. USA 2000, 97, 4086-4091. [CrossRef]

108. Bowe, L.M.; Coat, G.; de Pamphills, C.W. Phylogeny of seed plants based on all three genomic compartments: Extant gymnosperms are monophyletic and Gnetales' closes relative are conifers. Proc. Natl. Acad. Sci. USA 2000, 97, 4092-4097. [CrossRef]

109. Friedman, W.E.; Williams, J.H. Modularity of the angiosperm female gametophyte and its bearing on the early evolution of endosperm in flowering plants. Evolution 2003, 57, 216-230. [CrossRef]

110. Tobe, H.; Jaffre, T.; Raven, P.H. Embryology of Amborella (Amborellaceae): Descriptions and polarity of character states. J. Plant Res. 2000, 113, 171-280. [CrossRef]

111. Williams, J.H.; Friedman, W.E. The four-celled female gametophyte of Illicium (Illiciaceae, Austrobaileyales): Implications for understanding the origin and early evolution of monocots, eumagnoliids, and eudicots. Am. J. Bot. 2004, 91, 332-351. [CrossRef] [PubMed] 
112. Dilkes, B.P.; Comai, L. A differential dosage hypothesis for parental effects in seed development. Plant Cell 2004, 16, 3174-3180. [CrossRef] [PubMed]

113. Batista, R.A.; Köhler, C. Genomic imprinting in plants-Revisiting existing models. Genes Dev. 2020, 34 , 24-36. [CrossRef]

(c)

(C) 2020 by the authors. Licensee MDPI, Basel, Switzerland. This article is an open access article distributed under the terms and conditions of the Creative Commons Attribution (CC BY) license (http://creativecommons.org/licenses/by/4.0/). 